\title{
Containing the Past, the Present and the Future: Packing a Suitcase
}

\author{
ORVAR LÖFGREN \\ Department of Cultural Sciences, Lund University
}

\begin{abstract}
Everyday life is a constant negotiation between experiences and memories of the past, the challenges of the present and longings and anxieties about the future. My paper focuses on "the throwntogetherness" of such temporal frames. How are they synchronized or kept apart? My chosen example is the suitcase, which I will analyze with the help of two perspectives focusing on the acts of throwing together and containing, to explore how the past, the present and the future is organized, intertwined and stored. The mundane tasks of packing and unpacking will be explored in different contemporary and historical settings, among holidaymakers, migrants, commuters and refugees. The suitcase works as both a material and cultural container.
\end{abstract}

Keywords: mobility, luggage, suitcase, containment, throwntogetherness, temporalities

How do utopian visions, contemporary realities and heritages co-exist and how are they envisioned, practiced and entangled? This was the theme of the 2015 conference of SIEF (Société Internationale d'Ethnologie et de Folklore) in Zagreb. These are grand questions, which always run the risk of becoming too general and too abstract. They could be addressed by using one of the classic techniques of European ethnologists: that is, the linking together of seemingly small phenomena with larger issues, analytically starting in the mundane everyday and working upwards instead of the other way around. My chosen example is the suitcase, which I will analyze with the help of two perspectives focusing on the acts of throwing together and containing, to explore how the past, the present and the future is organized, intertwined and stored. ${ }^{1}$

\footnotetext{
${ }^{1}$ This paper has been developed out of a longer book chapter (Löfgren, forthcoming) in which the focus is on materiality and affect.
} 


\section{TRAVEL CONTAINERS}

I am walking through the aisles of the vast storage facilities of the Museum of Cultural History in Lund, Sweden. Travel containers take up shelf after shelf of space here. Rucksacks, trunks, handbags, miniature luggage for children, hat boxes, carpet bags, chests, suitcases...

Some have very specific functions, like the bridal chest with its special kind of gaze into the future. It waits patiently to be filled with textiles and dreams, year after year, and then be triumphantly carried along to the home of the newlyweds; or, it never makes that journey at all but stays, gathering dust and disappointment up in the attic. Then there is the sailor's chest, and the trunks of immigrants to America that are so full of objects and memories of distant worlds.

Most of these pieces of luggage share an aura of being containers of not only stuff but also of emotions, longings and memories. They are evocative objects. My guide, a museum curator, tells me that the museum is swamped with old pieces of luggage that people want to donate. They find it hard to throw them away, so full as they are of personal memories. For the museum, however, they are often dead knowledge.

Suitcases continue to live happily outside the museum. They are found everywhere in popular culture and the arts, as props and symbols, and as important co-actors in films, songs, literature and art. To give just one example, the suitcase plays a leading part in the film The Accidental Tourist, from 1988. The film features a travel writer who specializes in books for business travellers who want to avoid the foreignness and anxieties of travel and remain untouched by the exotic, eating in McDonald's whenever possible and wearing practical grey suits that do not stain. The film begins with the writer neatly packing a small suitcase and preaching about the necessities of packing light and keeping control of the future. This favourite carry-on case of his follows him throughout the film. When he moves in with a new woman, it remains unpacked next to the bed as a silent but menacing threat ("are you thinking of leaving me?"). When, in the end, he opts for a new life with her, he drops his beloved suitcase in a Paris alley before grabbing a taxi to the airport and leaving it behind him, filled as it is with his old life.

This example illustrates how suitcases can be many things: a condensation of the future, an icon of mobility, a nostalgic museum, a threatening or comforting object, a defence against a hostile world. They are objects into which temporalities and affects are crammed and intertwined in interesting ways. This makes the suitcase a perfect object for studying what Doreen Massey (2005) has called "throwntogetherness".

The concept of throwntogetherness focuses on the ways in which diverse elements come to cohabit in a setting or a situation, often as unexpected 
neighbours. Other scholars have explored similar ways in which humans and things, as well as sets of things, become co-dependant or co-actors (Hodder 2012) or are turned into culturally-charged assemblages (Bennett 2011). The kind of throwntogetherness I want to focus on deals with the ways in which people are busy packing not only stuff but also organizing the past, the present and the future at the same time.

My second analytical perspective deals with the power of containers and processes of containing. Containers produce a specific kind of throwntogetherness, shaped by the bounded and confined space that they offer. They contain, in many different senses of the verb: unite, hold together, separate, restrain and control. Containers are about boundaries of the inside/outside and are thus important tools for organizing movement and recategorizations. Objects, activities, emotions and ideas cross a boundary when they are placed inside or are taken out of a container, and these journeys are transformative. Jean-Pierre Warnier (2006: 193) puts it this way: "Making use of containers amounts to working with and on containment, that is, putting together the things, substances and people that are introduced into a common container." By sharing a bounded space the stuff inside a container starts to interact, sometimes in unforeseen ways.

Lewis Mumford (1934) pointed out that container technologies are among the most unappreciated (and understudied) among technologies. Containers, from boxes and jugs to chests, cabinets or other storage places, have often been seen as low-status, passive and, in a derogatory sense, "feminine" technologies, as Zoë Sofia (2000) has pointed out. But Sofia also reminds us that they play a crucial role in everyday life by protecting, separating and organizing matter. Once they are there, they also begin to demand to be used: people start looking for items or stuff to fill them with.

My suitcase discussion is part of a larger ongoing study of the mundane infrastructures and routines of travel, which are often taken for granted and thus made invisible. There are travel containers, such as the railway compartment and the hotel room, and then there are all the ways in which modes and moods of travel come together (see the discussion in Löfgren 2015a and 2015b). For these studies, as I also do here, I have used a bricolage approach of cultural analysis (see Ehn and Löfgren 2010: 217-227), combining very different kinds of materials, from interviews and observations, to travel handbooks and memoirs, advertisements, and discussions on the internet.

The ways in which people move, as commuters, migrants or tourists, are organized not just through infrastructures and devices but through conventions, routines and reflexes, and this also goes for packing a suitcase. In a sense, it feels like starting from zero; there is an empty vessel ready to be filled to the brim. Yet, at the same time, packing is an intensely cultural process, a competence people learn. The empty case is already full of pre- 
understandings and conventions. What to bring, and what not? And how to pack it? This is where material and technological potentials are entangled with travel logistics, social and economic resources and hierarchies, and cultural ideals and norms.

To explore such entanglements, a historical perspective is helpful in order to destabilize the taken-for-grantedness of the present. The suitcase belongs to the category Michel Foucault (1977) once called "objects without a history", mundane stuff that is taken for granted. It is important to understand the historical perspective, how an object becomes an institution through a winding route of possible routes and reroutes, and produces what James Gibson (1986) has called "affordances", an object's "potentialities for a particular set of actions". Even if you never have seen a suitcase before, the handle reaches up for the hand, the lid asks to be opened and the container filled.

\section{LEARNING TO PACK}

The old elites never had to worry about the actual packing, trained servants anticipated their needs and took care of the abundance of chests, boxes and trunks. This changed as mass travel by sea and rail accelerated in the late $19^{\text {th }}$ century. The new travelling middle class began to carry their own luggage, and an entire industry of trunk manufacturers developed.

Design had to fit the new travelling body. Questions of balance, size and weight had to be solved in interaction with the new ways of carrying - a suitcase body. Thus, an American luggage producer changed its name to "Samsonite", evoking the biblical strength of Samson. The suitcase became personalised, an extension of the travelling body. People began to decorate their suitcases with fancy hotel labels, and they also formed an attachment to "my suitcase"; it became a sensitive object, and in this process the fashion dimension was also accentuated.

The material history of this piece of luggage is important, because it illustrates how a commodity emerges in dialogue between technological development, transport logistics and cultural conventions. Such entanglements resulted in the modern suitcase and its presentation of a special kind of material affordance: a limited container, which people had to adjust to. The suitcase emerged out of new travelling needs, but it also came to redefine these needs.

The history of suitcases shows how the size and form of luggage help people select and deselect. Setting out with an invitingly empty case, it soon begins to overflow. What shall I pack? Only the necessities. And what might they be? Every item put into the case is briefly weighed up. Will I need this? 
Would it be good to bring this along, or fun to have it with me...? In a sense, packing becomes a micro-journey in itself, moving into the future. Skills of anticipation and planning are important, and such cultural skills are learned and relearned during a long travel career.

There has always been a wide range of instructions and manuals for learning to pack. Over time it is possible to see how the advice changes, reflecting different social contexts and situations. What was it necessary to bring in 1910,1980 , or in 2017, and for whom? Earlier generations found advice in travel handbooks, or from journalists and seasoned travellers. Later came a proliferation of internet-based guidance, from blogs by fashionistas and veteran tourists to the homepages of consultants and luggage vendors.

The most important learning, however, begins at home. Children start early, allowed to pack their own miniature suitcases but then having their parents go through their stuff and telling them what they can or cannot take. In their own playworld, however, they can pack whatever they want.

The Turkish author Orhan Pamuk (2006) remembers how he loved to unpack his father's suitcase after his father returned from his travels, handling the familiar and unfamiliar items, taking in the fragrance of eau-de-cologne and other scents of foreign parts. Another example is the man who talks of the ways in which he still meticulously follows his father's style of packing; he is performing a ritualised tradition.

Packing is a heavily gendered activity. There is a long tradition of condescending male remarks about women who pack too much, who ca not restrain themselves, which the sociologist Jean-Claude Kaufmann (2012) has explored in his study of the handbag. He points out that women, and especially wives and mothers, never pack just for their own needs but for those of others as well. It is the women's job to pack for future events, happenings or accidents. When a mother packs for a family holiday, she keeps adding stuff that is "good to have", as she plans for all kinds of eventualities and mishaps. Paper handkerchiefs, band-aids, aspirins and other first-aid things, an extra towel, a corkscrew, maybe some plastic mugs, suntan lotion, and much more. Her suitcase carries a heavy responsibility for future situations and her husband cannot understand why she takes such a long time to pack ("aren't you ready yet, darling"?)

Jean-Claude Kaufmann's study reminds us that learning to pack is also a question of selecting or combining different kinds of travel containers. What goes into the handbag and not into the suitcase? There are a number of other micro-containers. In the $18^{\text {th }}$ century, the Swedish gentry adopted the French invention of "le necessaire". The necessaire became the name for a small travel case for the very necessary things, such as pills, perfumes and toiletries. As ideas of personal hygiene changed, this small bag for travel toiletries becomes loaded with more and new items. Today, the politics of 
travel security has produced a miniature version of the necessaire with the small see-through plastic bag with our cosmetic secrets held up for inspection at airports. Other micro-containers are the wallet (Nippert-Eng 2010), the jewellery bag, the travel notebook and the smartphone. What should go where and why?

\section{PACKING FOR A NEW LIFE}

A film shows a man packing his suitcase. Meticulously, he places all the items he needs in the case: clothes, toiletries, and finally a hairbrush. His movements are swift but orderly; he is in a hurry to leave Europe for Israel. The film is part of a post-Second World War campaign to encourage Jews to leave Europe with all its recent horrors of the Holocaust and to help build the new state of Israel. The use of a suitcase scene is not a coincidence. The film seems to be in a silent dialogue with another situation of packing for a journey into the new and unknown: at Block 5 in Auschwitz, there is a large display of the suitcases that the camp's Jewish victims brought with them.

They had been instructed by the Gestapo to bring along a suitcase each, to create a reassuring feeling of a temporary move, and people were told to mark their luggage for later identification. The names are still there in block letters, with some carrying the extra label Waisenkind (orphan). Inside these suitcases, packed in haste, were belongings brought along on a journey to a new life. Most of the travellers thought they were heading for a stay at a work camp, but on arrival their suitcases were confiscated immediately and when the liberators arrived in 1945 they found stacks of them, emptied of their contents, which had been sorted for further use by the camp staff. Why do these piles of suitcases produce such strong emotional reactions among visitors? Unlike the heaps of skeleton parts or the cramped bunks in the barracks, the suitcases bring to the fore a sense of personal destiny. The cases may have been emptied but they are still loaded with anguish, hope and bewilderment. Although they rest there silently, they communicate action, the hurried packing of a few cherished belongings.

The suitcases at Auschwitz belong to the harrowing memories of packing for the millions of people forced out of their home as refugees or deportees in $20^{\text {th }}$ century Europe. The stories are remarkably similar. Often there is a knock on the door from the militia or the police, who give the order to get ready to leave in an hour or tomorrow. Bring only a suitcase with the necessary things. Necessary for what? In other situations, there is not even that much of a warning. In a panic, people just throw anything into the suitcase. During the deportation of Estonians to labour camps in Siberia, people remember how some just started cramming stuff into a suitcase without any 
idea of what was needed. If the soldiers knocking on the door were from the local militia, they occasionally gave a bit of advice. You should pack this but not that...

But, again, it is the container in the form of the one suitcase that frames the preparations for the journey. All over the world battered suitcases are still being dragged along, with people's belongings suddenly reduced to only the items that could be squeezed into the case. It is not surprising that a book on refugee voices from Bosnia and Croatia bears the title "The Suitcase" (Mertus et al. 1997), and in the texts suitcases appear in many ways. One woman remembers: "When we rushed out of our homes into the city, perhaps forever, I took some of my favourite books, a checkered vanity case, and undergarments." She asks her mother: "What did you bring?" - "That which everyone needs, she says" (Mertus 1997: 87). People remember what they forgot to pack in the frenzied hurry and what they managed to take with them. Another woman packed lots of warm clothes although it was the middle of the summer, but also a copy of Marcel Proust and a favourite scarf. Reading Proust in exile, with the scarf resting under a cushion, created a reassuring link with the past.

Another Bosnian war memory from 1992 underlines this stressful situation:

We heard the shelling coming closer to our town. A man shouted by the door, the last convoy out of here leaves very soon, hurry up! We ran around trying to pack, I didn't even find a suitcase, just threw stuff and clothes into plastic bags and left the house. ${ }^{2}$

Today, thousands of travellers pack for an illegal border crossing. For most of them, packing could not be more strategic; a negotiation of the absolute necessities, balancing between minimum weight and maximum chances for survival. Others may discover that their careful packing is of no use at all when the middlemen rob them of their only belongings during the journey.

Suitcases or travel bags also follow different kinds of migrants across the borders. The nature of the journey is mirrored in the packing (Frykman and Humbracht 2013). There are people who commute between double homes, to an overnight flat, a caravan, a hotel room away from home: migrant labourers, transnational professionals, itinerant salespersons.

Ida Winther (2015) has followed some of these double-homers and explored what they decide to bring with them between homes. The young teenager packs for journeys between her two divorced parent's homes. In a sense, it is the content of her weekend bag that links these two homes. Other travellers, like flight stewards, bring along small items to recreate something

${ }^{140}$ From an interview in 2015. 
of a home-like atmosphere in their impersonal hotel rooms. There is a constant traffic here between the past, present and future.

\section{LUGGAGE WITH FRICTION AND WITHOUT}

Suitcases and their bearers come to be linked in many ways. The travelling salesman walking the streets was easily identified by his suitcase full of samples. "Suitcase ladies" was a term given to women traders in the post-Soviet empire, who dragged their suitcases full of merchandise onto cheap flights and traded across borders. Their enterprise was effectively channelled and limited by the suitcase space available.

I am reminded of the union between luggage and traveller as I approach the identity check at Malmö's Central Station, in the southernmost part of Sweden, that was set up in the autumn of 2015 to control the growing numbers of refugees. Coming from Copenhagen airport, wheeling my neat carry-on bag, I am waved through quickly, while the migrants behind me, dragging along all sorts of luggage with them, from battered suitcases and backpacks to plastic bags, are stopped and scrutinized.

My brisk walking pace and my light carry-on bag signals that I probably belong to the category of mobile persons associated with a number of positive connotations. My case is loaded with the social and cultural capital of a desirable cosmopolitanism. I look like the kind of traveller that is supposed to carry promises of a future of economic growth and the transnational flow of ideas and creativity. Such desirable mobility should be made as frictionfree as possible with the help of frequent-flyer cards, VIP lounges and fast tracks, and whenever these travellers experience any delay, transit spaces are turned into work spaces by the flipping open of the laptop. They continually keep the wheels of the global economy turning.

I am also reminded of the seasoned traveller Ryan Bingham, the main character in Up in the Air (2009), a novel turned into a film. Played by the actor George Clooney, Ryan is a consultant who spends much of his life airborne on his way to new assignments all over the USA. His home is the airport lounge and the hotel. In an early scene, he is travelling together with a young woman whom he is supposed to be training to be a consultant like him. Her education begins when they meet in the departure hall. She is dragging along a large suitcase and a carry-on clothes wardrobe. This won't do, he tells her, and takes her to buy a cabin bag on wheels, and in the middle of the hall he begins to systematically sort out her stuff, putting most of into the wastepaper basket. Life is too short to check in luggage. Then he teaches her to scan the waiting lines to see where one can get through security the fastest and avoid the holidaying families and slow senior citizens. Step by step she is taught the routines that Ryan has turned into mere body reflexes. 
As a business traveller, Ryan has created a fantastic flow. The camera captures his elegant choreography as he glides with minimal friction through the security and ID controls, the hotel lobbies and waiting lines with his light and fast-rolling suitcase. With a perfectionist's delight, he swishes his gold and VIP cards, juggles the plastic trays at the security check, sailing through, finding fast lanes everywhere. It is not only his clothes that are wrinkle-free, his whole life is liberated from demanding relations or duties. He loves this no-man's land where you can always be in transit, travelling light. "Moving is living" is his motto. Watching him gliding through space is to see a man with a habitus that has perfected the union between body and luggage.

Then there are the travellers whose movements across borders can be discussed in other terms, as a challenging, problematic or threatening mobility. In the autumn of 2015 they were often described in the media as flows, waves, floods, or even "human tsunamis" - faceless, impersonalized masses, wading ashore on European beaches or trudging through fields or along narrow rural paths, dragging with them all sorts of various forms of luggage...

I am reminded of the Nigerian art curator Okwui Enwezor (1996: 65) describing his experience of the customs control at Charles de Gaulle airport, surrounded by other Third World migrants:

I hate being one of these people: the men and the women with their bundles, their world and dreams contained in bags and boxes long out of fashion. Even more, I loathe the pawing fingers of the coarse young French officer at Charles

De Gaulle, his rudeness and sullen manner, his angry inferiority complex.

In the autumn of 2015, there were heated discussions in anti-immigration circles about migrants who carried the wrong kind of luggage, not just the traditional bundles and battered cases but who had brand new backpacks or designer suitcases. By carrying the wrong kind of luggage these migrants were blurring the categories. Where these people, often middle-class refugees from a war-ravaged Syria, really needy and humble asylum seekers? They did not conform to the traditional European stereotypes of what refugees should look like as meek and helpless.

\section{THE SUITCASE IN THE ATTIC}

After a busy life, many suitcases have stopped travelling; they rest in attics, collecting dust and in this process they become a new kind of container. One such case belonged to Dmytre Zrchuk, which, when it was opened, was found to contain 199 items: fourteen paper patterns for cut-outs of various animals, a coloured print of the Madonna and Child from Innsbruck, a 
green scarf and three peach-coloured towels, an alarm clock, a hand-carved wooden dog, a bronze model of the Washington Monument, a photo album, a sewing kit, a silver fork and spoon, twenty-six postcards... books, dictionaries and pamphlets in German, Ukrainian and English. Zrchuk's suitcase was found in the attic of the Willard State Hospital in New York. When this mental institution was closed in 1995 and demolition crews moved in, two female employers remembered that there was some stuff stashed in the attic of the Sheltered Workshop Building. When they managed to pry the door open, they encountered an awesome sight over 400 trunks, suitcases and bags, luggage that patients had packed neatly as they prepared themselves for a stay at the hospital (Penney and Stastny 2009). They had carefully chosen what they thought they would need and what items they thought they would like to bring with them, from family albums to elegant clothes. Little did they know that they would never open them and that many of the inmates would spend the rest of their lives in this institution, while their cases lay forgotten in the attic. Over the years, these possessions gathered dust, frozen images of a journey planned, with a selection of necessary or beloved items. All they would need for their trip... Past, present and future materialized in a very powerful way.

There are other forgotten suitcases in attics around the world. In 1923, Olga from Gammelnäs in Sweden went to America and worked as a maid in a wealthy Boston family, while her fiancé Erik stayed at home, fishing and farming. When she came back sixteen years later, they raised a family and her Boston savings helped to buy the small farm they had longed for. Olga died young and after Erik's death in 1993, their daughter found her mother's old American trunks stowed away in the attic. They were filled with American clothes, embroidered silk blouses, stylish dresses, white gloves, Bakelite handbags and other wonders of the 1930s fashions, as well as untouched cosmetics, from nail polish to Luxor Complexion Powder, together with Boston theatre programmes, souvenirs and photos. They were things that a smallholder's wife in Gammelnäs had no use for, and could not show off back home. The trunks remained closed, up there in the attic, encapsulating a time that had been but which mattered little after her return from the exotic world "over there". In an instant, the daughter encountered a life unknown to her. The trunks had turned into an exotic time capsule and became an exhibit at the regional museum in Kalmar, Sweden.

\section{THE LIFE AND LABOUR OF SUITCASES}

Over the years, the suitcase has become a strong icon signalling very different images of desirable and undesirable mobilities. There are people who define their life as "living out of a suitcase", not just as a metaphor but as a 
real experience. Their personal bond with the suitcase is created above all by constant handling, packing and unpacking. In an interview with a young American woman she describes it as follows:

I feel I have been living out of a suitcase for so many years. Just like my friends, always moving between temporary lodgings and never really settling down. The case is always there, half-unpacked under the bed, signalling a state of impermanence and makeshift arrangements. The day it is emptied and put away in the attic, I know I have finally settled...

In a way, an old suitcase, which has been through a long life of packing and unpacking, is a good example of what Sara Ahmed has called stickiness: "affect is what sticks, or what sustains or preserves the connection between ideas, values, and objects" (Ahmed 2011: 29). The suitcase is an object that attracts strong feelings. When Orhan Pamuk's father died, he was left with a filled suitcase, as Olga and Erik's daughter in the example above was. Although he had opened it so often as a child, Pamuk found it hard to open it now; it seemed to be overflowing with affect. Was he ready to confront his father's past?

Why can it be so challenging to open someone else's luggage? What makes a suitcase or a handbag such a special container of stuff and mixed emotions? It is a particular kind of bounded universe. Analysing the life of the handbag, Jean-Claude Kaufmann (2012) asks how it is that mundane items in the supermarket or on a table, from tampons and underwear to corkscrews and pocketbooks, are just everyday stuff, but collected together in a suitcase or in a bag, they acquire a new aura of intimacy and often also of secrecy. The workings of throwntogetherness and containment turn them into a personalised version of "me". "Through what they choose to carry and not to carry with them, participants support specific narratives of self", as Christena Nippert Eng (2011: 147) says in her discussion of the wallet. Similarly, the suitcase contents can be a material condensation of a life, a home or a style of living. It is no coincidence that artists often use the suitcase as an identity container ("who could be the owner of this assemblage" or "open your suitcase and I will tell you who you are"). The contents can be turned into a micro-biography - this material collection is actually me.

By being included in the select company of other objects, things may acquire a special aura, turning into talismans. A small stone from a holiday beach, a couple of photographs, a poem or a wrinkled letter. This process is enhanced by having them close and handling them ("I just can't go without them"). One traveller kept a small, dog-eared card with a prayer for starting out on a journey (Nippert-Eng 2010: 111) - "It is nice to have", he said. But the longer such items rest in the travel bag or wallet, the more important 
they may become. They turn into more of a necessity than many other essentials. Even the illegal immigrants crossing the desert with only the absolute minimum often carry a small image of a saint.

A refugee from Estonia in the 1940s threw an old rusty pair of scissors into his suitcase before his hasty departure. When he unpacked the case in his new homeland, he realised that this item was now the only thing he owned that had belonged to his father and so in this process a mundane object turned into something else that was overflowing with affect.

A similar memory comes from the Bosnian war in 1992:

There's a knock on the door. Outside, a big bearded man with a gun. "You have half an hour to take the essentials and then leave. You should be glad I am not killing you right now." My parents run around in panic. Mother gives the man jewellery and money. He finds a comforter and throws it on the floor. I picked it up and had it with me for a long time. It belonged to my childhood. ${ }^{3}$

Margrit Wettstein has discussed similar processes in her study of Jewish refugees. The author Nelly Sachs, for example, escaped with her mother on the last civilian flight out of Berlin in 1940. She crammed a few clothes and some personal items, a few photos, her father's military decorations and a beloved childhood album of bookmarks into her suitcase. "With the Gestapo waiting, it was what you put into your pockets that came to remain of your home" (Wettstein 2009: 12).

\section{PACKING A TIME MACHINE}

What are suitcases good at? I have discussed what suitcases can do, and what people can do with them, in very different contexts. They are mundane objects that get dragged along, but they are also magic and sensitizing tools and represent a number of container skills: separating, uniting and compressing.

As both a physical and cultural container, the suitcase brings key cultural norms and ideals into play - the necessary, the essential, the indispensable, the optional, the superfluous - in very concrete ways. Trying to decide whether to make do with or without this or that, objects are weighed in the hand. The suitcase has room for both constraints and potentials. During its history, it has become a measurement for "enough". Over a century, the conservative form of the suitcase created special standards and packing is also done according to different genres. The suitcase's processes of containment do something to the traveller and her world.

\footnotetext{
${ }^{3}$ Interview in Dagens Nyheter, December 5, 2015, p. 11.
} 
My focus has mainly been on temporalities and time frames, real or fantasized. Some of the cherished stuff bought during a journey and carried home turns out to have no place there; its special aura evaporates as the suitcase is unpacked. Feelings that get packed may turn out to be ephemeral or "sticky". The suitcase can work as a portable utopia and a small heritage museum in canvas frames, but above all a materialized way of confronting the past, the present and the future.

I began by referring to Doreen Massey's evocative but somewhat elusive concept of throwntogetherness. She writes about the event of the place as throwntogetherness, a constellation of processes with no easy synchronization. "Thinking conjecturally suggests a shuttling back and forth between different temporal frames or scales to capture the distinctive processes which appear to inhibit the "same" moment in time, it is not a de-structuring, it is the coming together of different trajectories" (Massey 2005: 47).

I have used the suitcase to develop the analytical potentials of this term further. The suitcase creates special conditions for such temporal confrontations and to understand that we must look at processes of containing. The suitcase turns into a cultural container by this throwntogetherness, enclosing and joining together stuff that may be seen as a personal micro-universe. Stuff and feelings confront each other in sometimes unexpected ways, and objects become emotionally charged. This goes for both the carefully planned packing and the objects that are thrown in more or less at random.

In the strict containment of the suitcase, things are joined into what Jane Bennett has called a "confederate agency", or a vibrant assemblage (2010: 23). She analyses the agency and affective power of things, from a small collection of rubbish to a nationwide electricity grid, using Deleuze and Guattari's term assemblage as an example of a "confederate agency". Her starting example is a collection of trash at a roadside. She points out that an assemblage owes its capacity for agency to the "shi" effect: a Chinese term that describes something that is hard to verbalize:

the kind of potential that originates not in human initiative but instead results from the very disposition of things. Shi is the style, energy, propensity, trajectory or élan inherent to a specific arrangement of things. (Bennett 2011: 35)

The suitcase may carry strong "shi" effects, because it is a very special kind of container and assemblage. First of all, it is a container on the move between different contexts. Secondly, it is a micro-universe, a condensed version of a home or a life; the suitcase is turned into a very personal and private space, my own (sometimes secret) universe. Finally, its contents are constantly handled and rearranged. A number of "co-" verbs are at work here: cohabiting, confronting, contaminating, confusing, co-educating. In these ways, the 
suitcase handles a number of polarities in people's lives, such as private/ public, home/away, past/future. Packing and unpacking a suitcase means constantly negotiating such tensions and paradoxes.

For every object selected or left behind, a potential future is constructed: this weekend, my job trip, a family vacation, or a life-changing migration. Packing for possibilities, eventualities, disasters, or for dreams of fun. The business traveller who adds a packet of condoms or a seductive nightgown is certainly not planning an extra-marital affair, but then "you never know...". The suitcase looks ahead, but also backwards. People pack continuities. What elements of an earlier life demand to be taken along on a new journey? In this sense, packing can become a ritual of invocation, an attempt at controlling the future and materializing the past. Such practices are shaped by available container technologies.

In 1915, a Swedish factory girl who had moved from her village to a new factory job would keep her suitcase under the bed, packed not only with necessities, but memories from back home and dreams of a better future. The case would be opened now and then, and old letters, postcards and framed photos would be handled, but so would images and small talismans of a new world.

In 2015, a Chinese factory girl, who has left her village like millions of others, organizes the past, the present and the future in different ways, as Xinyuan Wang (n d) has shown in her ethnography. There is a travel bag, of course, but, more importantly, a cheap smartphone. Wang talks of how these girls have created a double migration, from village to factory towns, but also of a move into the digital world. It is in cyberspace that they have constructed new images of their home village and created a digital ancestral cult, a new past. At the same time they are constantly constructing a dream future, with images of a cool and modern life: icons of success like beautiful fashion models, elegant cars and furniture. A new past and a new future is created and the girls spend most of their free time online. Or, as one said, if life here in this factory slum is unbearable, your real life and hopes are on the internet.

Handling the past and the future through opening the lid of the suitcase and handling the things inside may produce a different sensibility than flicking through images on the smartphone, but we should be wary of seeing this contrast as an example of increased "shallowness" of experience. It is, rather, two material regimes of time travel, but also different regimes of containment.

During its over one hundred years of existence, the suitcase has turned into a material companion, as well as an icon, a mundane working tool but also a symbol with very different charges. The most intimate side of exile, for 
example, is tied to luggage, as the Croatian writer Dubravka Ugresic (2007: 17) writes as she looks at her suitcases:

my only true companions, a witness to my wanderings. The suitcases travel, go across borders, move in and out with me. If there is something I dream of, it is not a new home, but a new suitcase... East, West, home is best, most people would agree. But the majority is always wrong. East, West, suitcase is best!

\section{REFERENCES AND SOURCES}

Ahmed, Sarah. 2010. "Happy Objects”. In The Affect Theory Reader. M. Gregg and G. J. Seigworth, eds. Durham: Duke University Press, 29-51. [http://dx.doi.org/10.1215/9780822392781002]

Bennett, Jane. 2011. Vibrant Matter. A Political Ecology of Things. Durham: Duke UP.

Boscagli, Maurizia. 2014. Stuff Theory. Everyday Objects and Radical Materialism. London: Bloomsbury.

Ehn, Billy and Orvar Löfgren. 2010. The Secret World of Doing Nothing. Berkeley: University of California.

Enwezor, Okwui. 1996. "In Transit”. In Interzones. A Work in Progress. Octavio Zaya and Anders Michelsen, eds. Copenhagen: Kunstforeningen, 56-60.

Foucault, Michel. 1977. "Nietzsche, Genealogy, History". In Language, Counter-Memory, Practice. Selected Essays and Interviews. D. F. Bouchard, ed. Ithaca: Cornell University Press.

Frykman, Maja and Michael Humbracht. 2013. "Making Palpable Connections. Objects in Migrants' Transnational Lives". Ethnologia Scandinavica 43: 47-67.

Gibson, James. 1986. The Ecological Approach to Visual Perception. Hillsdale, New Jersey: Lawrence Erlbaum.

Hodder, Ian. 2012. Entangled. An Archeology of the Relationships between Humans and Things. Oxford: Wiley Blackwell. [http://dx.doi.org/10.1002/9781118241912]

Kaufmann, Jean-Claude. 2012. Privatsache Handtasche. München: UVK.

Löfgren, Orvar. 2015a. "Modes and Moods of Mobility. Tourists and Commuters". Culture Unbound. Journal of Current Cultural Research 7/2: 175-195. [http://dx.doi.org/10.3384/ cu.2000.1525.1572175]

Löfgren, Orvar. 2015b. "Staying in Hotels". In Popular Culture as Everyday Life. Phillip Vannini and Dennis Waskul, eds. London: Routledge, 275-286.

Löfgren, Orvar. [forthcoming]. "Emotional Luggage”. In Sensitive Objects. Jonas Frykman and Maja Frykman, eds. Lund: Nordic Academic Press.

Mertus, Julie, Jasmina Tesanovic, Habiba Metikos and Rada Boric. 1997. The Suitcase. Refugee Voices from Bosnia and Croatia. Berkeley: University of California Press.

Mumford, Lewis. 1934. Technics and Civilization. New York: Harcourt, Brand and Company.

Nippert-Eng, Christena. 2010. Islands of Privacy. Chicago: Chicago UP. [http://dx.doi. org/10.7208/chicago/9780226584546.001.0001]

Pamuk, Orhan. 2006. My Father's Suitcase. Nobel Prize Lecture. Available at: www.nobelprize. org. 
Penney, Darby and Peter Stastny. 2009. The Lives They Left Behind. Suitcases from a State Hospital Attic. New York: Bellevue Literary Press.

Sofia, Zoë. 2000. "Container Technolgoies". Hypatia 15/2: 181-201. [http://dx.doi. org/10.1111/j.1527-2001.2000.tb00322.x]

Ugresic, Dubravka. 2007. Nobody's Home. London: Telegram.

Wang, Xinyuan. (n d). A Story of Two Chinese Migrations. From Rural to Factory and from Offline to Online (A presentation at the workshop "How does everyday life remake media?", Lund University, June 8-9 2015.).

Warnier, Jean-Pierre. 2006. "Inside and Outside. Surfaces and Containers". In Handbook of Material Culture. Christopher Tilly, ed. London: Sage, 186-192. [http://dx.doi. org/10.4135/9781848607972.n13]

Wettstein, Margrit. 2009. Liv genom tingen/ Things that matter. Objects and People in Extreme Situations. Stockholm/Stehag, Brutus Östlings Bokförlag Symposion.

Winther Wentzel, Ida. 2015. "To Practice Mobility - On a Small Scale". Culture Unbound 7: 215-231. [http://dx.doi.org/10.3384/cu.2000.1525.1572215]

\section{SADRŽAVANJE PROŠLOSTI, SADAŠNJOSTI I BUDUĆNOSTI: PAKIRANJE KOFERA}

Svakodnevni se život sastoji od neprestanog balansiranja između iskustava i sjećanja prošlosti, izazova sadašnjosti i čežnji i briga za budućnost. Moj se rad temelji na "nabacanosti" navedenih vremenskih okvira. Na koji način ih sinkroniziramo ili razdvajamo? Raspravu temeljim na primjeru kofera koji analiziram na osnovi dviju perspektiva: čina nabacivanja stvari (u kofer) i njihova sadržavanja u koferu, da bih istražio kako su prošlost, sadašnjost i budućnost organizirane, kako se isprepliću i kako se pohranjuju. Prozaičnu aktivnost pakiranja i raspakiravanja promatram kroz različite suvremene i povijesne epohe, kod ljudi koji idu na godišnji odmor, migranata, ljudi koji putuju na posao i izbjeglica. Kofer ima ulogu materijalnog ali i kulturnog spremnika.

Ključne riječi: mobilnost, prtljaga, kofer, sadržavanje, nabacanost, privremenost 